\title{
Reclaiming the Power of Thought
}

Dewey's Critical Appropriation of Idealism

\section{Jörg Volbers}

\section{(2) OpenEdition \\ 1 Journals}

Electronic version

URL: http://journals.openedition.org/ejpap/1327

DOI: 10.4000/ejpap. 1327

ISSN: 2036-4091

\section{Publisher}

Associazione Pragma

\section{Electronic reference}

Jörg Volbers, «Reclaiming the Power of Thought », European Journal of Pragmatism and American Philosophy [Online], X-2 | 2018, Online since 11 January 2019, connection on 03 May 2019. URL: http://journals.openedition.org/ejpap/1327 ; DOI : 10.4000/ejpap.1327

This text was automatically generated on 3 May 2019.

\section{(c) $(1)$}

Author retains copyright and grants the European Journal of Pragmatism and American Philosophy right of first publication with the work simultaneously licensed under a Creative Commons AttributionNonCommercial-NoDerivatives 4.0 International License. 


\title{
Reclaiming the Power of Thought
}

\author{
Dewey's Critical Appropriation of Idealism
}

\author{
Jörg Volbers
}

\section{AUTHOR'S NOTE}

I thank James Matthew Fielding for a very productive criticism of earlier drafts of this paper; and Paul Giladi for the invitation to write on that subject and for his comments on the pre-final version.

\section{Introduction}

1 How 'idealistic' is Dewey's philosophy, and why should we care? This article attempts to answer both questions by taking a closer look at Dewey's criticism of idealism and Kantian philosophy. Its aim is to reconstruct the systematic reasons for Dewey's selfunderstanding as someone who gradually "drifted away from Hegelianism" (LW 5: 154) and from 'idealism' in a broad sense. ${ }^{1}$ This does not mean that we should take Dewey's reconstruction of idealism as the last word on that subject. Quite to the contrary: I am sympathetic with current research which tries to show how much Hegel there still is in Dewey (Bernstein 2013), or which points out how pragmatism's critique of idealism is unfair, or that it at least overstates their differences (Emundts 2013; Pinkard 2007; Stern 2011). But setting aside the question of its accurateness, Dewey's criticism of idealism is motivated by reasons which are important on their own. For what is at issue in Dewey's distancing from idealism, I want to claim, is the correct understanding of rationality. Dewey accuses idealism of closing our self-understanding as rational beings by intellectualizing it. Thus, by looking more closely at Dewey's relation to idealism, we gain a better understanding of his own alternative understanding of rationality and its systematic motivation.

2 One implication of this approach is that we should focus on Dewey's mature philosophy. Dewey himself started his career as an idealist and then moved into the direction of 
pragmatism. But it is not until the appearance of Experience and Nature (1925) that his emancipation of his own idealist roots took full shape and Dewey's alternative position came into fuller view - a position which he also explicitly dissociated from pragmatism, which he eventually took to be a misleading and therefore inapt classification for his work (cf. LW 12: 4). Thus, we will have to take the vantage point of these later works if we want to gain a comprehensive understanding of the systematic grounds of Dewey's criticism of idealism.

Given Dewey's own early idealistic leanings, it is no surprise that Dewey's criticism of this tradition is far from a simple rejection. It operates against a background of great sympathy for the general direction of that tradition, and of Hegelianism in particular. For Dewey, idealism rightly highlights the human power to lead a rational life, thus defending a modern emancipation from theology and dogmatism. Idealism stands up for the power of critical reflection as well as for the constructive capacity of reason to determine normatively binding values. In other words, it is an articulation of the free and selflegislating power of the human being. Thus, Dewey's criticism shares a common ground with idealism's modern affirmation of the critical power of reasoning. However, Dewey accuses idealism of ultimately missing its main objective, by devising an all too rationalistic defense of reason, putting too much weight on concepts, logic and wideranging systematicity.

4 Focusing on this break seems to me particularly important with respect to Hegel. Hegel is nowadays often read in a rather humane, post-metaphysical and, yes, even pragmatist manner, as a social philosopher and as a defender of the varieties of experience (Pippin 1989; Pinkard 2002). From such a perspective, to accuse Hegel of holding an abstract metaphysical 'conceptualism' - as Dewey seems to do - appears to be old-fashioned, onesided, or even simply wrong (Stern 2005; critical: Horstmann 1999). Yet, as I want to point out, Dewey's criticisms of idealism are not just exegetical. They express the wish, and even the felt cultural need, for a philosophy which actually does make a difference to the way we understand ourselves. In particular, his criticisms stand for the hope that philosophy can and should not be left to an intellectual elite. Idealism, with its demanding and highly elaborated philosophical concepts, its speculative metaphysics and its comprehensive aspiration, is not a natural candidate for such a democratic form of philosophy. So, rather than focusing on the hermeneutical correctness of Dewey's understanding of idealism, I want to show how, by opposing certain aspects of that tradition, Dewey is attempting to reclaim the importance of the same philosophical question of rationality for ordinary life and everyday reflection that, on one possible reading, idealism originally sought to secure but failed to do so.

5 Consequently, the central theme of Dewey's mature philosophy becomes 'experience,' rather than 'the concept' or 'the self,' as in the idealist tradition. This is more than just a pragmatist appropriation of an Hegelian theme; it expresses a new set of priorities. Idealism, as Dewey understands it, conceives rational thought in terms of conceptual understanding, thus giving conceptual relations methodological and even ontological priority. For Dewey, by contrast, thinking is subordinated to experience, and it therefore only "occupies an intermediate and mediating place" (MW 10: 320; cf. also LW 1: 372). Knowledge, likewise, is not an end in itself, but has always to be evaluated with respect to the role it plays in concrete experience: "all intellectual knowing is but a method for conducting an experiment" (MW 10: 324). Dewey considers thinking to be itself a form of experience and not the other way around, thus highlighting the constitutive non- 
cognitive, temporal and open dimension of all thought. Justly or unjustly, Dewey takes idealism to offer an account of reason which ultimately ignores such non-cognitive ways in which we are related to the world.

6 For reasons such as these, Dewey's position is of more than mere historic interest. For ultimately, Dewey's criticism aims at idealism as a representative of what he calls 'intellectualism.' 'Intellectualism,' for Dewey, signifies the widespread philosophical belief that rational thought is only concerned with explicitly articulated knowledge and cognitive content. This perspective, Dewey claims, ultimately misses the embedded and holistic nature of thought, as well as its relation to that what is not itself part of cognitive operations. It is this 'intellectualist' way of treating philosophical problems, against which Dewey objects, and on which we have to concentrate in order to better understand his break with idealism.

7 From that perspective, we will see that Dewey's criticism opens up an important systematic option for contemporary philosophy. His rejection of the excessive valorisation of pure reason antedates a well-known and even well-trodden path in the philosophies of the 20th century. Phenomenology, post-structuralism and critical theory all agree that modern rationality is, if one might say so, excessively rational, and even dangerously so, by understanding rationality precisely in that 'intellectualist' sense. Moreover, they all took issue with idealism's heritage, for this reason. As we now know, however, this discussion is too often framed in binary terms which are themselves deeply problematic - take, for example, Dreyfus' (2006) phenomenological opposition of 'conceptual determination' vs. 'bodily coping,' or Adorno's (Adorno \& Horkheimer 2016) claim that enlightened thinking constitutively ignores the subtleties and nuances of experience, even violently so. Foucault once called this modern constellation the "blackmail of the enlightenment": we seem forced to take sides, either for rationality or against it, and depending on our choice, we can be accused of either excessive rationalism or obscurantism. Ironically, from this perspective, the classical idealist systems, due to their anti-dualistic monism (Horstmann 2004: 25f.), seem more advanced and more contemporary than ever.

8 Dewey's way to face the danger of excessive rationalism is to put the notion of 'experience' at the heart of his understanding of rationality. Yet that move alone does not constitute a depart from idealism. Dewey joins the idealist tradition in criticizing empiricism for what we call nowadays the 'myth of the given.' Thus, Dewey shares the idealist understanding that experience is inherently rational and hence intimately connected with human understanding. Experience is not something brutely given; values, meanings and purposes are to be defended as a rational part of the world, not as mere projections upon it. Along with the classical idealists, Dewey believes in the constructive and even constitutive role of reason in the formation of knowledge by experience. Dewey's main problem with idealism, however, is that it does not put enough trust into experience, hedging it within the confines of 'Reason' with a capital 'R.'

Idealism, Dewey objects, explains the permeating rationality of experience at the expense of any actual experience and its unruly possibility to irritate thinking. A common expression of Dewey's final judgment on idealism is his statement that it exclusively identifies "the object of knowledge with reality, equating truth and Being" (LW 1: 126). Here Dewey sees idealism under the influence of a deeply problematic philosophical tradition which identifies the knowledge of reality with philosophical knowledge, and thus treats reality solely as an object of thought. This understanding of philosophy is a part of 
'intellectualism' in the sense mentioned above: It gives undue priority to knowledge when it comes to articulating our relation to the world, and moreover, it institutes philosophy as the final arbiter of any claim to reality.

10 Dewey's systematic point, as I understand it, is that there is no need for philosophy to define in final terms what 'rationality' is or what it amounts to. If there is a need, it is common to all kinds of human self-reflection and not specific to philosophy. Rationality is something natural; it is embedded in organic life; and it is only one part of what makes human life special (the other parts being communication and linguistically mediated sociality in particular). Dewey's position is comparable to Wittgenstein's criticism of philosophy, that it is not satisfied until it has proven that language works, ignoring in the meantime that language has in fact long being doing the very kinds of work required to reach that conclusion at all. Likewise, the idealist is not satisfied until he has proven the ultimate importance and the final form of rationality on some metaphysical level. Dewey, on the other hand, offers a defense of what one might call the 'ordinariness' of reason. To use one of Dewey's favorite methodological terms: he wants to reconstruct rationality, rather than to explain its particular power.

11 Thus, along with the idealists, Dewey accepts the idea of rationality as a driving force in the organization of life. Thinking opens up new possibilities of control and mastery, it is indeed 'autonomous,' as idealism claims - but only if we understand autonomy as constitutively bound to 'heteronomous' factors. Thinking, as Dewey understands it, only works by cooperating with non-thinking aspects of the world, such as tools, signs, bodies; or generally, by making use of circumstances and forces 'external' to thinking as such. Contra idealism, what makes thinking rational, then, is that it is exposed to an uncertain future, and that it is determined by habits which are never completely under its control. But showing that the very operation of reason depends upon time and upon the contingencies of the situation is no surrender of its critical autonomy. ${ }^{2}$ The idea is rather that reason can only solve its problems by linking its own fate with such 'this-worldly' factors. We are "dependent rational animals," to pick up a phrase from Alasdair MacIntyre (2002). This statement is no contradiction, as if rationality required independence. We are rational precisely because we are dependent.

In what follows, I will develop this argument in three steps. The first, covered in sections 2 and 3, will reconstruct Dewey's estimation of the philosophical tradition as a response to the ineliminable practical risks of living. 'Thought' seems to be such a promising candidate for philosophical reflection since it promises order in a life full of uncertainty. Idealism, as I will show in section 4, adds a specific flavor to that traditional high esteem. It argues for what we can call the 'thesis of the irreducible human contribution.' According to this thesis, all knowledge and experience is irreducibly bound to the structure of the thinking (human) mind, and thus also dependent on it. In consequence, every reflection on how we relate to the world also has to take into consideration how we relate to ourselves. But idealism, Dewey claims, misconceives this idea by articulating it in purely intellectual terms - this is the 'intellectualism' I have been introducing above. Dewey's own positive conception, to which I turn in the last section, accordingly highlights that the effectivity of thought can only be explained by reference to that what is not thought - a constitutive difference which the idealist tradition mistakenly tries to close off. 


\section{The Promise of Thought}

13 opposition to that tradition. Such a claim from Dewey's side requires a preconception of
what 'thinking' is, empirically, prior to any philosophical rationalization. The building blocks for such an account can be found in his pedagogical writings (How we Think, Democracy and Education) and are developed at some length in Reconstruction in Philosophy, in The Quest for Certainty and Experience and Nature. Dewey's approach is historical. Thinking is not anthropologically or transcendentally given; rather, it has been culturally discovered and cultivated. We have to look at this history in order to understand what is at issue with this concept (cf. LW 1: 126).

14 Dewey sometimes sounds like he is describing the real ('empirical') nature of thinking, it is an essentially open term. History provides material, but no final judgments on the matter. What thinking 'really' is, has to be determined again and again through thinking itself: "We do not know what meaning is to be assigned to 'reflective thought' except in terms of what is discovered by inquiry into inquiry" (LW 12: 29). So Dewey's historical observations should not be taken as disclosing some hidden origin of thought. Rather, they provide conceptual landmarks for his own 'inquiry into inquiry.'

Philosophical interest in thought and thinking, according to this historical approach, is continuous with the ordinary, everyday interest in thought and thinking. It picks up cultural preconceptions and articulates them. Philosophical theories might eventually break radically with ordinary life, but they begin by responding to a commonly experienced practical feature of thought. By thinking, the human being seems to be able to introduce order into a world full of contingency and disruption. Thus, there is a practical ground which justifies Western philosophy's traditional preoccupation with knowledge, reason and rationality (LW 4: 234). In Dewey's words:

The striving to make stability of meaning prevail over the instability of events is the main task of intelligent human effort. (LW 1:49)

Rationality, according to this understanding, is a means to generate stable meanings over and against an inherently unstable world. Note that Dewey's description implies a gap between thinking (what he calls "intelligent human effort") and the "instability of events." Firstly, thinking is concerned with the "stability of meaning," as opposed to the stability of events. Therefore, its foremost task is to understand and to describe the change of events, not to stabilize them in the sense of 'fixing' them. ${ }^{3}$ Furthermore, thinking is only described as 'striving' to fulfil this task, implying that even this more modest goal will often be frustrated. This reservation is well expressed in the classical understanding of philosophy as the love of wisdom, and not wisdom itself, which Dewey embraces (cf. MW 11: 43).

Dewey's rather wide and historic conception of thought distances itself from the modern identification of thinking with scientific rationality. In Dewey's perspective, by contrast, the scientific treatment of problems is only one way of thinking among many possible others. Its value stems from the particular role scientifically warranted knowledge can play in experience, rather than from the rigorous systematic or logical form this kind of inquiry assumes. Yet Dewey is not (pace Rorty 1979) simply renouncing the need for epistemology and epistemological justification. Rather, he conceives epistemological

European Journal of Pragmatism and American Philosophy, X-2 | 2018 
thinking as one region within the wider area of thinking in general. Knowledge is special insofar it has to be true to the events; but there are many more ways to investigate the meaning of events than just scientific knowing. As Dewey puts it: "Beyond this island of meaning which in their own nature are true or false lies the ocean of meanings to which truth and falsity are irrelevant" (LW 3: 4). The overarching goal of thinking, according to this understanding, is to give significance to the course of events, not to control or to predict it.

Keeping in mind the distance between thought and its possible real effects helps to avoid a reading of Dewey's remarks that is too heavily pragmatist. Dewey consciously avoids the rather short-sighted position that thinking is valuable only because of its efficacy. On the philosophical battleground, such an argumentation would indeed amount to a simple petitio. Dewey would thus project a pragmatist criterion of efficacy onto the history of thought, but only to use it as purported 'evidence' for the defense of his own, pragmatistleaning, understanding. Such an approach would imply that utility is the only criterion of all thought, and thus define thinking, instead of registering its different forms, as Dewey wished.

The deeper systematic issue, however, is that such a purported pragmatist preconception of thought would cut through the recursive definition quoted above. Thinking is what thinking determines itself to be, according to the objective needs of the situation. This self-referential definition is not an evasion of philosophical responsibility, but an expression of the necessity to keep the means of reflection responsive to varying historical and cultural demands. According to Dewey, any form of reflection is a possible response to some experienced rupture in thought or action, that is, to the thoughtprovoking experience that a situation has become "indeterminate" (LW 12: 109). The adequate determination of the individual problem at hand, whatever that may be, might call for new methods and concepts. Thus, thinking has to remain sensitive to the need for change and amendment, as required by the subject-matter at hand: "All materials of experience are equal [...] each has a right to be dealt with in terms of its own especial characteristics and its own problems" (LW 4: 172). In order to do justice to the wide variety of problems experienced, a wide variety of thought is required.

Thought, according to Dewey, is therefore discussed better in terms of its potential. Accordingly, Dewey's history of thought is a history of the discovery of new promising potentials of thought and the subsequent historical work of determination of these ideas. The experimental empirical method of the natural sciences, for example, had to be formed ; it was neither simply given, nor created at a single stroke (LW 4: 77). Yet Dewey insists on a common thread running through all the forms of thinking which might possibly emerge - they have the power to find order in chaos: "When thinking is successful, its career closes in transforming the disordered into the orderly" (LW 1: 60).

Here we come to the core of Dewey's empirical description of thought. In thinking, we are able to reach necessary or determinate conclusions which can orient our actions. This work is done by integrating an uncertain phenomenon within a wider context. One of Dewey's (characteristically medical) examples is the knowledge of typhoid fever: Issuing such a diagnosis means being able to do something about it, instead of succumbing to the mere 'what-ness' of the symptoms manifested. More precisely, through the diagnosis, the phenomenon becomes a symptom, from which an indication of possible ways of treating the illness follows (LW 4: 234). This example focuses on epistemology and its potential to guide human actions; but it can be generalized to all cases of successful thinking which 
enable us to relate to an initially problematic phenomenon, be it an illness, a puzzling smile or the unsettling experience of a modern artwork. ${ }^{4}$ Thinking transforms "the unclear and ambiguous into the defined and unequivocal," it changes the "disconnected into the systematized" (LW 1: 60). Note that the 'unity' implied here is not to be confused with 'harmony'; it denotes a merely formal integration of the event into a network of meaning which itself is full of tension and contradiction.

The necessity discovered by thinking is valuable because of its stark contrast to the precarious and contingent nature of action. Living is a practical activity; there are always things which need to be done. But Dewey never tires of reminding us that no practical activity is ever secure: "Doing is always subject to peril, to the danger of frustration" (LW 4: 27). This statement, and the many others like it found in Dewey's work (cf. LW 4: Ch. 1, or LW 1: Ch. 2), are not empirical observations. They point rather to the fundamentally contingent nature of action. Since every action is temporal, it requires the agent to act in what might be described as a 'subjunctive mood': We act as if we know where our actions will lead to, but the result of any action, even that taken from within the most controlled settings, can always fail to meet our expectations.

In action, therefore, we are by necessity focused on something which has yet to turn out to be what we expect from it, and we are ourselves in turn dependent on this course of events. This unavoidable transitory structure of action (and of organic life in general) makes thinking stand out. It promises to disclose necessary structures which prevail even when the events themselves disappoint. Thus, Dewey's systematic argument is to point to a normative gap between our understanding of a situation and its resistant reality. The quest for certainty is not simply the quest to get hold of what is valuable, in terms of possession or ownership. It is the quest, rather, to know what one is about. The certainty it seeks is a formal feature of any successful normative relation which enables us, say, to identify an object, or to recognize a valuable action, or to know how to judge someone's behavior. Thinking is primarily concerned with those normative relations, and only in a secondary sense with tangible results.

Again, thinking is kept at a distance from reality: it works with relations which are certain precisely because they are normative, and at a remove from the actual course of events. In this way, thinking can provide stable terms of judgment, standards of correctness, and justifications of goals, desires and values. Its primary goal is to ensure "the validity of intellectual beliefs" (LW 4: 32; my emphasis), as Dewey points out. The fact that these beliefs can, and most often will, stand out in stark contrast to the real course of life, actually enforces the importance of thought. The intellectual problem always remains the same: to know whether the situation is at least rightly understood. Such an understanding might be given in terms of a scientific explanation or in terms of a meaningful narrative of another sort; it might involve religious beliefs or restrict itself to a strictly secular standpoint; but it is still thinking - a means to relate to the world in a more meaningful way. According to this conception, then, philosophy's task, to which we turn now, is to explain that particular power of thinking.

\section{Explaining the Power of Thought}

The previous section outlined Dewey's understanding of thinking as a natural, everyday process, and thus, like all other natural processes, as an historically unfolding event. Intelligent reflection is a means to secure, establish and re-establish normative relations 
('meanings') which promise to make sense of what is happening. This conception is not particularly pragmatist. What is pragmatist, though, is Dewey's additional claim that thinking should eventually expose itself to the consequences of real events, because that is where, for Dewey, its genuine authority arises (LW 4: 110). For it is such attention to consequences that separates responsible inquiry from mere wishful thinking.

It is important to keep in mind, however, that Dewey is not claiming that other philosophical conceptions of rationality are simply wrong, nor is he claiming that they are irrational. Quite to the contrary: given the recurrent gap between thinking and reality, nothing is more natural and self-evident than to explain the integrative power of thinking by reference to some ultimate, transcendent order to which thought maintains a privileged access. After all, philosophy participates in the general human concern to reach the "greatest attainable security of values" (LW 4: 28).

In consequence, the historical dominance of the "spectator theory of knowledge" (LW 4: 14) within philosophy is no accident. Far away from being a simple mistake, it constitutes itself a rational way of explaining thought. Separating the "realms of knowledge and action" (LW 4: 14) allows to make sense of that impressive stability pertaining to the products of thought. Compared to the ordinary vicissitudes of life, the products of thinking seem to be so superior that they must spring from some other source. Since temporal, practical activity is by definition exposed to the danger of failure and the risk of misunderstanding, thinking seems to be an activity of a completely different order. The normative power of thinking, along with its demonstrable (albeit limited) capacity to find and establish necessary relations, is attributed to a stable and stabilizing realm on its own.

Accordingly, 'reality,' in the philosophical sense, is identified with that stability and located in the stable order of thought, as opposed to the ordinary world of changing phenomena and shifting appearances. In this traditional view, the power to make sense of the world is due to cognitive apparatuses participating in this other-worldly sphere. ${ }^{5}$ Idealism, in Dewey's eyes, shares this traditional approach to some degree, as we will see in the next section.

\section{The Human Contribution}

The observation of the previous sections sheds some light on Dewey's complex relation to idealism, the central topic of this article. We have seen that for Dewey, the power of thought is empirically given; but what remains contentious is how to explain, and to further determine, that power. Dewey's criticism of idealism, then, focuses on this second step. According to Dewey, idealism rightly claimed that knowledge, value and meaning can be both objective and a human product; this view vindicates the power of thought. In doing so, idealism acknowledges the rise of modern science and its impressive power to understand, and to change, the world in unprecedented ways (LW 1: 125f.). But it wrongly construed this relation in purely intellectual terms, Dewey claims.

In terms of the historical narrative just presented, idealism accepted that rational thought does indeed have a power that makes a difference. In order to explain that difference, idealism points to experience. Human experience is not completely 'alien' to the thinking human mind; it is dependent on the categories, the norms, the concepts and the beliefs the mind entertains. Furthermore, this infusion of the human mind to 
experience does not devalue the power of thought. Quite to the contrary: thought, idealism claims, has the power to disclose objective features of reality only because of that junction of mind and experience. In this way, idealism comes to acknowledge what I call the 'human contribution' to all experience (cf. for Dewey's analogous use of that term, LW 10: 250-75). For Dewey, recognizing the human contribution to all knowledge is essential to modern philosophy and cannot be taken back. But idealism went astray, Dewey claims, in conceiving this empowering link between thought and world only intellectually, that is, mainly in terms of thinking and knowing.

31 One problem with Dewey's criticism, however, is that it addresses 'idealism' in a very general and abstract way. It can be profitably compared with references to 'the skeptic' in some contemporary discussions: they point to a general attitude within philosophy, not to some specific author. ${ }^{6}$ That might have been an important strategic move in Dewey's times, when idealism was a well received (though already stumbling) contemporary option. Yet historically, 'idealism' covers many different positions, beginning with Fichte, Schelling and Hegel - the classical German idealists - up to British idealism and its American reception (Green, Bradley, Royce). In particular, there are many different ways to address the 'thinking mind' in idealism, ranging from Fichte's I to Hegel's Geist up to its various later interpretations. All of these varieties imply different concepts of what reason, rationality and thinking are like - take, for example, Hegel's distinction between the Objective Spirit and the Subjective Spirit, which are both rational and yet can hardly be said to 'think' in the same way. Dewey's diagnosis lacks the depth and the cogency of a detailed study. His remarks about idealism, if not simply directed at 'idealism' in general, often refer rather vaguely to philosophers he considers to be idealists, without a detailed discussion of the authors or the concepts in question. ${ }^{7}$

Instead of discussing Dewey's position towards a specific idealist author, then, it seems more productive to follow Dewey's own understanding and to use 'idealism' as denoting one fundamental option within classical modern epistemology. This option is based on the Kantian claim that the object of knowledge is determined by thought..$^{8}$ In Dewey's view, that claim is more than just a piece of epistemology. It further implies that all knowledge and experience is only to be had with that irreducible human contribution to it. According to that claim, knowledge is never simply forced on us. Rather, knowledge is an expression of an active relation to the world, on the part of the 'self,' the 'subject' or the 'mind.' There's no knowledge, no value, no meaning, not even a habitable world, without this specific human contribution. In consequence, the power of thought becomes itself a specific human power, and cannot be taken anymore to be aiming at a pre-existing nonhuman truth.

33 According to Dewey, then, we have to see idealism primarily as defending the central modern idea of rational self-determination. This idea, embodied in the Kantian 'Copernican Revolution,' allows idealism to defend modern human freedom as an emancipation from theology and rationalist metaphysics, Dewey claims (LW 4: 229-30). It identifies rationality with criticism and grants it the power to conform only to those standards and measures it can rationally approve of. It points to the possibility of living a self-determined life in a world that is not alien to us. ${ }^{9}$

Such a view on idealism is still widely held today..$^{10}$ We can trace it back to Kant's claim that the categories of experience are the work of the faculty of the understanding, which in turn is considered as belonging to the transcendental rational nature of the human being. Of course, Kant's original claim raises well-known problems and paradoxes, such as 
epistemological skepticism, an all-too mechanistic understanding of nature, or the problem of the justification of the allegedly 'transcendentally given' categories of the mind (cf. Horstmann 2004: 25-69). However, the idealist critics of Kant - Fichte, Schelling and Hegel - were not trying to question the main idea of rational self-determination. Rather, they sought to defend this claim by setting it up on more intellectually solid ground. What is common to them all is the conviction that our experience of the world, in one way or the other, is the product of the activity of the mind. That human factor, idealism claims, is an indispensable ingredient of all knowledge, without which any given experience would be normatively inert and thus without meaning. ${ }^{11}$

Kantian and post-Kantian philosophy thus dramatically extend the classical philosophical search for self-knowledge. As a consequence, the ancient call to 'know oneself' cannot be limited anymore to practical matters only. If reality, or at least our knowledge thereof, depends on the specific ways our mind is constituted, that very constitution moves to center stage of philosophical reflection. There simply is no way to find out what reality 'really' is, or what it can possibly become, without figuring out what concepts, categories and norms we do contribute to it. Thus, all philosophical subject-matters turn into questions concerning our relation to the matter discussed. Furthermore, this relation cannot be reduced to the contact between 'subject' and 'object,' as the post-Kantian debate in idealism has shown. Hegel, for example, extends the constitutive dimension of the mind, upon which philosophy has to reflect, to the dynamic development of nature, history and society on a grand scale. Idealism, thus conceived, adds reflexivity to the quest for certainty to a degree hitherto unknown. Importantly, the acknowledgment of an irreducible human contribution further introduces a new dimension of philosophical responsibility. Kant's famous opening sentence of the first edition of the Critique of Pure Reason illustrates that point:

Human reason has this peculiar fate that in one species of its knowledge it is burdened by questions which [...] it is not able to ignore, but [...] it is also not able to answer. ${ }^{12}$

Reason, Kant claims, plagues itself with questions which cannot be answered because they are wrongly put. For that reason, Kant's critical philosophy wants to dissolve these questions. They rest on a self-understanding that is wrong, because it is uncritical, Kant claims. Here, the quest for certain knowledge is turned against the inquirer itself. Thus, the Kantian way of questioning rationality, as Conant (2012) shows, actually adds a further reflective turn to classical Cartesian skepticism. While Cartesian doubts only bear on the possible contents of thought, Kantian-inspired skepticism expands them to the very forms of reasoning itself, the way reason is structured. Philosophical reflection, thus, is not exempted from doubt. In consequence, any non-dogmatic judgment about the world also has to consider our very understanding of such a judgment, that is, our critically reflected understanding of ourselves.

Dewey's mature criticism of idealism has to be seen against this heightened sense of reflective responsibility introduced by that philosophy. In Dewey's eyes, idealism's acknowledgment of the human contribution remains half-hearted. The idealist authors rightly point out that in answer to Kant's question 'How is knowledge possible?' a reference to the forming and intervening activity of the human mind is unavoidable. Yet they conceive this activity from a traditional perspective, Dewey claims. According to idealism, as Dewey understands it, knowledge is made possible by belonging to an encompassing structure of the $I$, the mind or the spirit; that is, the activity in question is 
delegated to the internal working of this structure. Idealism, Dewey thus claims, again locates "the ideal authority of truth, goodness and beauty" in an ultimate structure of being (LW 1: 52). It "fails to note the empirical concrete nature" of inquiry (LW 1: 61); it is "guilty of neglect that thought and knowledge are histories" (LW 1:126).

It is easy to misunderstand these criticisms, in particular with respect to Hegel. Dewey seems to overlook the eminently practical character of Hegel's philosophy, his criticism of abstract thinking and overly unrealistic ideals; and Dewey seems to be particular ignorant of Hegel's dialectical insistence that all concepts have to realize themselves by way of confrontation with that which is not conceptualized yet. But Dewey's real target is the overall philosophical attitude. He actually speaks in high terms of Hegel's "glorification of the here and now" (LW 4: 51), but he mistrusts the "schematism" (LW 5: 154) of Hegel's general philosophical approach.

40 As a consequence of that approach, the initial responsible insight into the human contribution is again cast into a grand metaphysical scheme or logic. For idealism, the concrete singular experience is of cognitive and moral value only insofar it remains "prophetic of some final, all-comprehensive, or absolute experience, which in truth is one with reality" (MW 3: 128). In doing so, the effectiveness of thought, the power of understanding, is attributed to an overarching structure - at the expense of the specific individual actions and the present aspirations.

41 Traditional intellectualist philosophy, thus, drives a wedge between idealism's own acknowledgment of the human contribution and its articulation of that idea. Post-Kantian idealism, Dewey claims, is forced to oscillate between two poles which it cannot really unite. It insists on thought as "operative and constructive" (MW 3: 133), that is, it insists on the importance of thought as a regulating agency, as an intervening force that makes a difference. But idealism also feels obliged to rationalize being itself, and thus treats thought as a part of the ontological layout of reality (cf. also LW 1: 60). Thought, then, becomes itself a given (that's the Kantian variant) or is declared to be becoming itself (most prominently in Hegel).

The point now is that this second, ontological strategy undermines the original insistence on thought's regulative power. It makes it hard to explain that there is something to be gained by further reflecting on thought in its regulative function. That way, the newly gained responsibility for thought is evaded again. All changes in the structure of thought have to be either denied, or they have to be attributed to the ontological process itself, thereby bypassing our current desires and struggles. In any case, 'thinking' is located on such a remote, philosophical plane that it is far removed from actual experience and its needs and pressures.

Dewey's criticism, thus, aims at preserving what we could call, following Haugeland (1998), the existential dimension of rationality. Understanding ourselves is something that matters, and it matters precisely because we are, in reflecting, as idealism points out, forced back upon ourselves again and again. But idealism is led astray by consistently situating that rational self-reference within a structure detached from the current situation, in the existential sense.

The problem, then, is of a practical nature. Dewey wants reflective thought to remain a vital option. Since the very way we think makes a difference, the ways of thinking themselves must remain open to reflective change. They have to be responsive to the given situation. Like a tool, thought is supposed to do its work; but it has to be open to 
modifications as well as to alternatives. Consequently, any conception of rationality which is interested in preserving thought's flexibility has to move beyond intellectualism. It has to attribute a determining role to the non-thinking, embedding context of thought. Due to its exclusive focus on knowledge and logic, intellectualism cannot cope with that existential and experiential background of thought proper.

Ultimately, the rejection of intellectualism amounts to the claim that thought is temporal in its very nature, and not due to some secondary limitations of the finite human mind. The very fact that thought matters to us is itself already not a purely intellectual fact, that is, it is not something to 'know' or even to 'prove' by means of distanced logical deduction. Thought matters insofar as there is something at issue, something that is as yet indeterminate, unknown, opaque; in pragmatist terms: thought is a response to a problematic situation. Looking at that problematic situation from the standpoint of knowledge and theoretical certainty, intellectualism reduces this problematic situation to a mere intermediary step towards greater knowledge. As a consequence, it subordinates the process of thought to its results. For Dewey, though, thought has to be fully accepted precisely in this temporal dimension in order to even make sense of its results.

Maybe the best way to summarize Dewey's criticism is to say that he does not only want to keep thought open for continual revision, as most modern philosophers do. Additionally, he wants to defend the existential relevance of this openness and reflexivity. Not just thinking, but also the ways we think do matter for us, individually, in the situations in which we happen to be. Idealism, one could say, evades this existential dimension by arresting thought metaphysically. This evasion, though, is due to a deeper underlying issue, that runs throughout the philosophical tradition as a whole: the attitude of 'intellectualism.' In line with this attitude, idealism equates knowledge with reality in its fullest sense. It overlooks the fact that knowledge matters because it is part of something that is not knowledge, or at least not reducible to it - what Dewey variously refers to as 'situation, 'problem,' or simply 'experience.' The next section will clarify a bit further how that relation of thought to non-thought, which constitutes Dewey's antiintellectualism, should be understood.

\section{Decentering Thought}

We can now sum up the narrative of the preceding sections. Idealism, in Dewey's eyes, combines a correct insight with a problematically traditional attitude towards explaining that insight. Idealism is right to connect the power of thought with the specifically human contribution to experience. This insight allows idealism to acknowledge that the products of intelligence are not simply given, but made. The concepts we use, the categories through which we experience, the norms we are bound to - they all contribute to experience. Thus, our understanding of the world and of ourselves profits from reflecting upon that human contribution; we might think here about Kant's dismissal of certain question as simply wrongly put. Yet this reflexivity, Dewey argues, is essentially a practical problem, which cannot be explained away via a logical or conceptual schematisation. Idealism remains 'intellectualist' insofar as it believes that this reflexivity is something which itself needs to be established in terms of knowledge.

Granted, the terminology Dewey uses to tell that story can at times be a bit misleading. In particular, the charge of 'intellectualism' evokes an opposition to the classical understanding of rationality, whereas Dewey is actually aiming at its defense. Dewey's 
position should not be confused with the general vitalist distrust of concepts, such as that which can be sometimes found in James. ${ }^{13}$ On the contrary, Dewey believes firmly in the power of knowledge to guide actions and to secure valuable practices. Dewey's point is not to dismiss rationality, but rather to insist that rational thought is constitutively bound to that which his not thought.

In this final section, I will add some clarifying remarks to that central idea, which will complete this survey of Dewey's charge against idealism. For Dewey, the power of thought cannot be explained only by reference to the human contribution alone. Such an explanation also has to focus on what we could call the 'differential nature' of thinking, which denies that there are any stable and final identities both of thought and of human nature.

We can introduce this idea by recalling that thinking is, for Dewey, always a response to what he calls a 'problematic situation.' The term 'problematic' has an irreducible existential aspect. A problematic situation is not just something puzzling, but an experience of "tension," of being full of "doubts" or of being unsure how to proceed (cf. LW 12: 109). It is an experience of incompatible ways of continuing action (LW 4: 189). Therefore, the problematic quality of a 'situation' is to be understood temporally. It expresses that there is something at stake insofar as the further development of the situation is unsure and calls for a resolution.

51 This problematic situation, now, is not just the negligible origin of thinking or its cause; it also constitutes its "working context" (MW 6: 88) from which intellectualism abstracts. Thinking, for Dewey, does its work by introducing directed changes to that specific individual situation. It is related to that situation in an essential way, in the same way the organism is constitutively related to its environment. Organic interaction establishes a pattern which "foreshadows" this operative scheme of rational thought, as Dewey claims (LW 12: 40).

52 But while changing the environment is something every organism does, thinking constitutes a distinct way to interact with the situation. First of all, it is an indirect response, which first restrains from immediate and spontaneous action in favor of the right solution (LW 4: 180). Secondly, as a response, it includes the responding subject itself as a contributing factor to the situation (LW 4: 185f.). Both aspects are linked together. What is inquired into is how our own possible contributions to the situation might, in their consequences, change the situation.

53 As Godfrey-Smith (2016) points out, the change instituted by thought might be restricted to a change in our mere understanding of some elements of the situation. It does not need to be a physical external change. To use Godfrey-Smith's own nicely suggestive example: Once we understand how to crack a nutshell open, its contents become immediately accessible to us, even if we do not go any further and leave the nut itself untouched. What matters is the new potential found by thinking. But note also that this description of change still conforms to Dewey's claim that his theory “introduces no elements save such as are public, observable, and verifiable" (LW 4: 182). If we claim that we have understood something, this claim has to manifest itself in our actions, i.e. in the way we treat nuts or in the way we talk about them. In sum, thinking results in organizing experience in a different way, which in turn manifests itself in ways of acting. New possibilities present themselves, previous impasses fade away. 
Thinking, then, is constitutively dependent on this 'working context' in which thinking is called for. An important consequence of this claim is that we do not always think. We are living an organic and habitual life, in which thought is an option, but not a permanent reality. However, there is, Dewey adds, a possibility to foster thinking by cultivating doubt and creative imagination: "The scientific attitude is that which is capable of enjoying the doubtful" (LW 4: 182). In any case, thoughtful inquiry is only one possible response to a doubtful situation, other possibilities being, for example, direct emotional or habitual responses (cf. LW 4: 180f.). Furthermore, since thinking is the most indirect and most open type of response, it is not necessarily superior to other, more spontaneous reactions.

Yet there is a reason why thinking, for us, seems to be so ubiquitous and so pervasive. We are accustomed to thinking as the preferred way to treat problems, since we live in a world which is itself formed by thought. The ordinary world is replete with products of thought; thought is embodied in tools, signs, language, institutions and practices. Yet these products of thought, again, are not themselves forms of thought. They are used by thought because of their consequences and their acquired logical form, for they have proven to be useful in one way or the other. But the often quite seamless process of their application, its ordinary effectiveness, is an experiential fact and cannot be taken for granted. Every new instance of their application might prove that our conception of these tools and concepts was wrong, or partial, or incomplete.

the relative ease and prevalence of everyday thinking is the product of our acculturation into a human environment which is formed by thought, but which is not identical with it. The problematic situations we commonly encounter, as well as the available means of response, belong to an encompassing set of compatible intellectual and normative relations embodied in our culture. They are the historical result of continuous and related changes being made to the human environment. We do not begin anew in each problematic situation; we define, tackle and change it with more or less established concepts and instruments. Thinking is "re-organization" (LW 1: 61), as Dewey aptly puts it, and not a magical intervention ex machina.

7 Taken this way, another aspect of thought's constitutive ties to that what is not thought comes to the fore. The very process of thinking, according to Dewey, requires the introduction of factors 'external' to thought. This refers to habits, concepts, or material tools which allow us to introduce concrete changes in experience. Dewey discusses these factors in his Logic, under the heading of the "matrix of inquiry" (LW 12: 7-102). They establish the wider context out of which inquiry grows, and, more importantly, on which inquiry has to draw in order to do its continuous work.

The functional necessity of such a 'matrix of inquiry' is particularly evident with respect to the historically accumulated materials just referred to. In order to effectively transform the problematic situation, thinking has to intervene in the course of events by introducing materials which are not yet part of the situation. The problem being exactly that the given situation does not resolve itself on its own, any conscious attempt to make sense of the situation has to introduce such 'external' material. This material connects the problematic situations with reliable, already existent ways of interaction, thus reintegrating the elements of the situation into a wider, historical context. In Dewey's own example, a certain "speck of light" in the telescope of the astronomer is identified as a star, and thus receives a new intellectual treatment. ${ }^{14}$ Such an introduction of 'external' 
conceptual and material tools allows to approach the problematic situations in new determinate ways.

But the dependency of thought on 'external' tools, concepts and material, also applies the other way around. For Dewey, the material used has no ultimately fixed meaning. Its use is, essentially, experimental. We expect it to do some work, but it might turn out otherwise. Thus, the repeated use of the material used does not leave them untouched as a means of reflection. In re-using existing concepts or instruments, we also learn something new about their individual power. We learn to differentiate their use or to limit our understanding of their potential: "use re-shapes the prior materials" (LW 1: 217). Therefore, thought's differential relation to non-thought is not only a condition of the possibility of the operation of thinking itself. It is also a condition of the possibility of changing thought, by changing its instruments, habits and ways of acting.

\section{Conclusion}

Our exposition of Dewey's differentiated position towards idealism comes to a close. For the purposes of this paper, the short outline of Dewey's positive understanding of 'thinking,' as it has been just presented, will suffice to illustrate the main point. We have seen how thought is constitutively bounded to that which is not thought. Thought, first of all, is temporally bounded. It is a response to the situated experience that something is wrong. Furthermore, the results of that process of thinking can be anticipated, but they cannot be taken for granted; they have to be realized. Thought, secondly, is materially bounded, insofar as this activity requires tools, practices and habits that are already available. This 'external' material is necessary to introduce new possibilities for acting and thinking in the specific situation. Both dimensions are joined in the historic process of refinement, further articulation and the subsequent differentiation of thinking. Tool 'use' is always 're-use'; the used tools themselves are re-shaped by their subsequent use in novel situations. Thought, to sum up, is experientially bounded, insofar as the problematic situation creates the relevant frame of reference within which thought has to find an answer.

61 All of these points support Dewey's rejection of what he considers the 'intellectualism' at the heart of the idealist tradition. His main point is that the intellectual relation to the world, and 'knowing' in particular, constitute just one kind of interaction with the world among others. Moreover, knowledge only has a specific value because of this difference. Knowledge, Dewey explains, is a "differential term." Its meaning is defined by the contrast it has to that which is not knowledge - such as "ungrounded conviction," "mere guess-work" or "the [practical] inexpertness that accompanies lack of familiarity" (MW 6: 112). Likewise, thought only stands out in comparison to other ways of responding to a problematic situation.

We are now in a position to finally formulate an answer to our initial question. How 'idealistic' is Dewey's philosophy, and why should we care? Dewey's philosophy is 'idealistic,' we can say, insofar as it acknowledges what I have been calling, following Dewey, the 'human contribution' to all experience. There is no experience, no value, no knowledge without a contribution from the human mind. At the same time, we can add, Dewey departs from idealism by criticizing it for treating that dependency in merely intellectualist ways. 
63 But why should we care about Dewey's distinctive treatment of idealism, and of intellectualism in general? In what sense is it important to discuss idealism's 'human contribution'? Because it is, in its core, a discussion of freedom. In this concluding section, I am not able to expand that claim more thoroughly (see Volbers 2018 for a more elaborated defense). But I hope it has become clear that Dewey's criticism of intellectualism is not just extending the list of factors which constitute human thought and experience. It further expresses the claim that only such an anti-intellectualist treatment of the relation of thought and experience is the right way to keep thinking open and reflectively sensitive to change. Understanding the 'human contribution' implies to understand that our specific contribution to experience, our culture, ideals and cognition, can never be spelled out in a final manner. There is no ultimate, culturetranscending answer to the question what 'we' are and what 'we' can become, because the meanings of our acts and practices continuously intertwine and shift in the course of time. Thus, according to Dewey, the most rational way of self-understanding is to remain open for change. Not only scientific norms and practices, but also our own selfunderstanding should be, in that sense, fallible.

Such an openness to change now is, for Dewey, a necessary condition for freedom. Remember that 'thinking,' in Dewey's use of the term, denotes more than just formal deduction and epistemological knowledge. It ranges from historical inquiry to formal logic, it includes works of art as well as ordinary attempts of conscious problem solving and political action. A change in thinking, then, is in a fundamental way a change in who and what we are. This is where, for Dewey, freedom resides: "We are not free because of what we statically are, but inasfar as we are becoming different from what we have been" (LW 3: 108). This understanding of freedom is also the basis of Dewey's conception of democracy as a way of life. According to Dewey, democratic freedom is a social and cultural constellation which leaves as much room as possible to the diverse forms and the continuous reworking of experience: "Democracy is the faith that the process of experience is more important than any special result attained" (LW 14: 228).

Dewey's claim about freedom, thus, can be seen as an expression of the wish to leave the answer to the question 'What are we?' open to experience. This is definitely not a comforting wish. But it succeeds, at least in my opinion, in reclaiming the idea that precisely because thinking is a difference that makes a difference, philosophical and nonphilosophical forms of thought do matter. These practices and their norms do contribute to our possibilities of living, to the better and to the worse, and thus are rightly conceived of as objects of further criticism and reflection.

Ultimately, the possibilities of changing our ways of thinking, and the responsibility resulting from such possibilities, should not be evaded. Neither by reducing thought to a mere form without practical relevance or footing, nor by passing its development over to speculative metaphysics on a grand scale. By decentering thought, Dewey is centering it once again on its importance and relevance. 


\section{BIBLIOGRAPHY}

ADORNO Theodor W. \& Max HORKHEIMER, (2016), Dialectic of Enlightenment, London, New York, Verso.

BERNSTEIN Richard, (2013), "Hegel and Pragmatism," in Alan Malachowski (ed.), The Cambridge Companion to Pragmatism, Cambridge, Cambridge University Press, 105-23.

BLOoR David, (2017), "The Question of Linguistic Idealism Revisited," in David Stern \& Hans Sluga (eds.), The Cambridge Companion to Wittgenstein, Cambridge, New York, Cambridge University Press, 354-82.

CAVELl Stanley, (1979), Claim of Reason, Oxford, Oxford University Press.

CAVELl Stanley, (2004), Cities of Words. Pedagogical Letters on a Register of the Moral Life, Cambridge, MA, Harvard University Press.

CONANT James, (2012), “Two Varieties of Skepticism," Rethinking Epistemology, 2 (edited by Günter Abel \& James Conant), 1-73.

DREYFUS Hubert L., (2006), “Overcoming the Myth of the Mental,” Topoi, 25 (1-2), 43-9.

EMUNDTS Dina, (2013), “Idealism and Pragmatism: The Inheritance of Hegel's Concept of Experience,” in Nicholas Boyle, Liz Disley, \& Karl Ameriks (eds.), The Impact of Idealism, Cambridge, Cambridge University Press, 347-72.

GILADI Paul, (2017), "Idealism and the Metaphysics of Individuality," Philosophy \& Social Criticism, 43 (2), 208-29.

GODFREY-SMITH Peter, (2016), "Dewey and the Question of Realism,” Noûs, 50 (1), 73-89.

HAUGELAND John, (1998), Having Thought: Essays in the Metaphysics of Mind, Cambridge, Mass., Harvard University Press.

HILDEBRAND David, (2003), Beyond Realism and Antirealism: John Dewey and the Neopragmatists, The Vanderbilt Library of American Philosophy, Nashville, Vanderbilt University Press.

HORSTMANN Rolf-Peter, (1999), "What Is Hegel's Legacy and What Should We Do With It?," European Journal of Philosophy, 7 (2), 275-87.

HORSTMANN Rolf-Peter, (2004), Die Grenzen der Vernunft. Eine Untersuchung zu Zielen und Motiven des Deutschen Idealismus, 3rd ed., Frankfurt am Main, Klostermann.

MACINTYRE Alasdair, (2002), Dependent Rational Animals: Why Human Beings Need the Virtues, 2nd ed., Chicago and La Salle, Open Court Publishing Company.

MCDOWELL John, (1996), Mind and World: With a New Introduction, Cambridge, Mass., Harvard University Press.

MOUNCE Howard O., (2005), "Wittgenstein and Classical Realism," in Danièle Moyal-Sharrock \& William H. Brenner (eds.), Readings of Wittgenstein's On Certainty, Houndmills, Basingstoke, Hampshire, New York, Palgrave Macmillan, 103-21.

PINKARD Terry, (2002), German Philosophy 1760-1860: The Legacy of Idealism, Cambridge, Cambridge University Press. 
PINKARD Terry, (2007), “Was Pragmatism the Successor to Idealism?," in Cheryl Misak (ed.), New Pragmatists, Oxford, Clarendon Press, 142-68.

PIPPIN Robert B., (1989), Hegel's Idealism : The Satisfactions of Self-Consciousness, Cambridge, Cambridge University Press.

RORTY Richard, (1979), Philosophy and the Mirror of Nature, Princeton, Princeton University Press. SHOOK John R. \& James A. GoOD, (2010), John Dewey's Philosophy of Spirit: With the 1897 Lecture on Hegel , 1st ed., American Philosophy, New York, Fordham University Press.

STERN Robert, (2005), "Peirce on Hegel: Nominalist or Realist?," Transactions of the Charles S. Peirce Society, 41 (1), 65-99.

STERN Robert, (2007), "Hegel, British Idealism, and the Curious Case of the Concrete Universal," British Journal for the History of Philosophy, 15 (1), 115-53.

STERN Robert, (2011), "Hegel and Pragmatism," in Stephen Houlgate \& Michael Baur (eds.), A Companion to Hegel, Wiley-Blackwell, 556-75.

VOLBERS Jörg, (2018), Die Vernunft der Erfahrung. Eine pragmatistische Kritik der Rationalität, Hamburg, Meiner.

WILLIAMs Bernard, (1973), "Wittgenstein and Idealism," Royal Institute of Philosophy Lectures, 7, 76-95.

WITTGENSTEIN Ludwig, (1967), Philosophical Investigations, 2nd ed. reprinted, Oxford, Blackwell.

\section{NOTES}

1. Following the convention, all quotes from Dewey are taken from the Collected Works, ed. by Jo Ann Boyston, Carbondale.

2. For a much more detailed defense of this thesis, see Volbers 2018.

3. Cf. Dewey's description of the organism as a means to establish constant meaning in a constantly changing environment (LW 12: 37).

4. Dewey's example is fire (cf. LW 1: 181f.). Already treating it as an object of worship is a form of thinking, limited as it is.

5. For a good description of classical realism, though with respect to Wittgenstein, see Mounce 2005.

6. Cf. the figure of 'the skeptic' in Cavell's Claim of Reason (1979). One telling example of Dewey's rather generalizing treatment of idealism can be found in his Brief Studies of Realism. After claiming that idealism has made the "ubiquity of [the knowledge] relationship its axiom," he quotes Bain (!) as evidence. Dewey takes this single quotation to be fully representative of idealism in general: "One sample is as good as a thousand" (MW 6: 112). Later discussions, such as in Experience and Nature or Quest for Certainty, are somewhat more detailed, but serve only to reinforce his previous judgment.

7. The 1897 lectures (Shook \& Good 2010) show that Dewey actually had good knowledge of idealism and in particular of Hegel, and that it was quite modern and 'non-metaphysical,' as the editors of that volume point out.

8. For a detailed reconstruction of Dewey's debate with contemporary idealists, which focuses on that claim, see Hildebrand (2003: 30-87).

9. A contemporary version of this idealistic vision can be found in McDowell (1996: 118): "the world is where the human being is, where she is at home." A recurring problem is, of course, how 
much negativity is allowed, to make some room for internal disruption and development, but without breaking that basic relation. Hegel's speculative metaphysics can be seen as the attempt to allow as much negativity as possible while still holding fast to the basic claim of an 'identity' in all differences (cf. Stern 2007; Giladi 2017).

10. Horstmann reconstructs the history of idealism on this premise; he calls it the "Aufklärungsthese" (Horstmann, 2004: 27) - the thesis of enlightenment. Pinkard's (2002) reconstruction highlights the Kantian idea of unconditioned moral autonomy as a driving force in the development of German idealism.

11. Incidentally, this is also the power of language, as Wittgenstein (1967) argues. Philosophy of language, thus, has always had a strong affinity to idealism (Williams 1973; Bloor 2017).

12. Quoted from Cavell (2004: 128), who sees that statement as expressing "[the] idea of the human as a burden to itself."

13. Cf. MW 6: 86-91, where Dewey separates his avowed 'anti-intellectualism' from James's, and also LW 1: 49.

14. Dewey uses this astronomical example in LW 8: 238; cf. also LW 1: 115.

\section{ABSTRACTS}

The article presents Dewey's own understanding of rationality by reconstructing his criticism of idealism. For Dewey, idealism is an important and valuable expression of the modern idea that both knowledge and values are historical products of human self-determination. Thus, it rightly defends the power of thought against the uncritical claims of mere religious and social authority. Yet idealism, Dewey claims, still misconceives that human power by ultimately treating it as a merely intellectual power, thus following the philosophical tradition. For Dewey, however, human thought and reasoning have to be understood in a much broader way. Dewey decenters thought by arguing that it is a natural, dependent and essentially temporal process, in which the intellectual elements only play a subordinate role. Thought, he claims, does not only have a history; furthermore, thinking only matters to human beings precisely because it is open to reflective change. Dewey's position, thus, can be seen as an attempt to preserve the existential importance of philosophical self-reflection by binding thought to history and change in a radical way.

\section{AUTHOR}

\section{JÖRG VOLBERS}

Freie Universität Berlin

joerg[at]joergvolbers.de 